\title{
Cover Page: Bio-Inspired Calix[4]arene Additives for Crystal Growth Modification of Inorganic Materials
}

\author{
Franca Jones, Mauro Mocerino, Mark I. Ogden, Allan Oliveira and Gordon M. Parkinson*
}

Nanochemistry Research Institute, and AJ Parker Cooperative Research Centre, Department of Applied Chemistry, Curtin University of Technology, GPO Box U 1987, Perth, Western Australia, 6845, Australia

\begin{abstract}
Crystal growth of inorganic materials, calcium carbonate, barium sulfate, and calcium oxalate, was studied in the presence of calix[4]arene additives functionalized with aspartic or glutamic acids at the lower rim. The additives were synthesized by reaction of the appropriate amino acid ester with 5,11,17,23-tetra-tert-butyl-25,26,27,28-tetrakis(chlorocarbonylmethoxy)calix[4]arene, followed by controlled hydrolysis of the ester groups. Both additives inhibited the nucleation and growth of calcium carbonate, but induced different changes in calcite morphology. The aspartic acid derivative was the more potent barium sulfate inhibitor at low concentrations, with comparable performance at higher levels. Both additives induced a polycrystalline barite precipitate. The aspartic acid functionalized calixarene also stabilized calcium oxalate dihydrate at low additive concentrations, whereas the glutamic acid derivative induced morphological changes in calcium oxalate monohydrate.
\end{abstract}

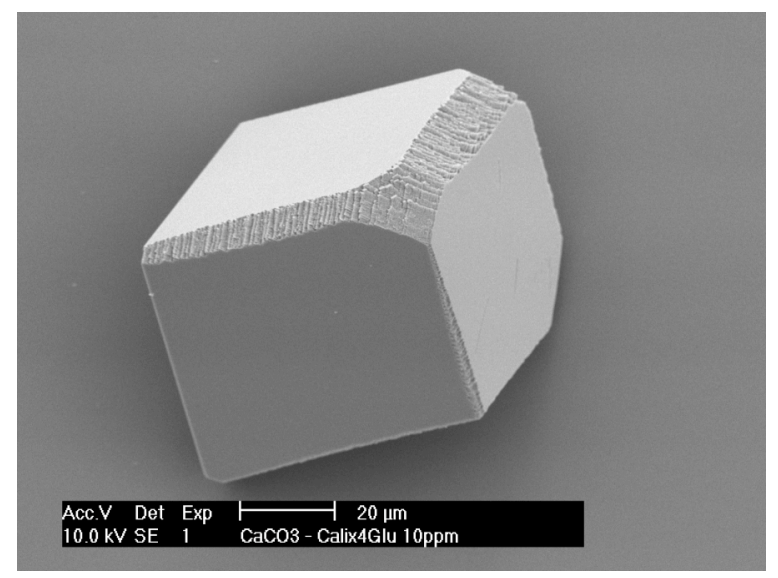

Graphic: Fig 2(b) showing that glutamate additive 2 stabilises both the $\{11.0\}$ and $\{01.2\}$ faces of calcite

Professor Gordon Parkinson

Nanochemistry Research Institute

Curtin University of Technology,

GPO Box U 1987,

Perth, Western Australia, 6845, Australia

Phone +6189266 3838

Fax +6189266 4699

E-mail: G.Parkinson@curtin.edu.au

Web: www.nanochemistry.curtin.edu.au 


\title{
Bio-Inspired Calix[4]arene Additives for Crystal Growth Modification of Inorganic Materials
}

\author{
Franca Jones, Mauro Mocerino, Mark I. Ogden, Allan Oliveira and Gordon M. Parkinson*
}

Nanochemistry Research Institute, and AJ Parker Cooperative Research Centre, Department of Applied Chemistry, Curtin University of Technology, GPO Box U 1987, Perth, Western Australia, 6845,

Australia

AUTHOR E-MAIL ADDRESS G.Parkinson@curtin.edu.au

\section{RECEIVED DATE}

ABSTRACT: Crystal growth of inorganic materials, calcium carbonate, barium sulfate, and calcium oxalate, was studied in the presence of calix[4]arene additives functionalized with aspartic or glutamic acids at the lower rim. The additives were synthesized by reaction of the appropriate amino acid ester with 5,11,17,23-tetra-tert-butyl-25,26,27,28-tetrakis(chlorocarbonylmethoxy)calix[4]arene, followed by controlled hydrolysis of the ester groups. Both additives inhibited the nucleation and growth of calcium carbonate, but induced different changes in calcite morphology. The aspartic acid derivative was the more potent barium sulfate inhibitor at low concentrations, with comparable performance at higher levels. Both additives induced a polycrystalline barite precipitate. The aspartic acid functionalized calixarene also stabilized calcium oxalate dihydrate at low additive concentrations, whereas the glutamic acid derivative induced morphological changes in calcium oxalate monohydrate. 


\section{INTRODUCTION}

The impact of organic molecules on the crystallization of inorganic materials is important in areas including biomineralization, ${ }^{1,2}$ hydrometallurgical processing, ${ }^{3}$ and crystal engineering ${ }^{4}$. In the context of biomineralization, it is well established that proteins rich in glutamic and aspartic acid residues are found associated with biologically formed materials, particularly calcium carbonate. ${ }^{5,6}$ It has been shown, for example, that proteins rich in glutamic acid are associated with amorphous calcium carbonate in an ascidian skeletal structure, whereas proteins containing aspartic acid residues are associated with the crystalline component. ${ }^{7}$ In vitro studies of these proteins showed significant impact on the crystal growth of calcium carbonate, consistent with their location in the organism. Based on such observations, a number of reports describe the synthesis of acidic peptides, ${ }^{8-10}$ and other polycarboxylates, ${ }^{11}$ designed to interact with calcium carbonate. Despite this activity, a direct relationship between additive structure, crystallization environment and the polymorph and morphology of the crystalline product is yet to be elucidated. ${ }^{12}$

Our approach to this problem is based on our previous studies of crystal growth modifiers with systematically altered structures. ${ }^{13}$ The amino acid components found to be active in Nature, are placed on a simple, readily synthesized, structure that is completely distinct from the natural system. In this case, we have chosen the calix[4]arene macrocycle as a framework to which the active moieties can be attached. Using well established chemistry, the calix[4]arene can be "locked" in the cone conformation, directing the amino acids to one side of the additive molecule. ${ }^{14}$ The conformational freedom of the molecule is thus somewhat limited. Ultimately, the impact of a range of subtly varying additives upon the crystal growth of a number of different inorganic systems will be used to establish structure-activity relationships that can be tested against natural and artificial additives with different structures.

Macrocyclic crystal growth modifiers have not been widely studied; examples include phosphonatefunctionalised aza macrocycles as barium sulfate modifiers, ${ }^{15}, 16$ and calcium carbonate growth at carboxylated porphyrin monolayers. ${ }^{17}$ Of particular relevance here is the recent report of calcium 
carbonate crystal growth under carboxylated calixarene monolayers at the air-water interface. ${ }^{18-20}$ The outcome of this work, in agreement with other recent reports on calcium carbonate growth at monolayers, ${ }^{21}$ was that the crystal growth is not controlled by a template effect of the specific calixarene or monolayer structure. ${ }^{19}$ We have found that a calix[4]arene functionalized with four aspartic acid moieties is appreciably water-soluble, and we have recently reported the impact of this additive upon the crystal growth of calcium carbonate and calcium oxalate. ${ }^{22}$ Here, we report the synthesis of the aspartic and glutamic acid functionalized calix[4]arenes, and their impact on the crystal growth of calcium carbonate, calcium oxalate and barium sulfate.

\section{EXPERIMENTAL SECTION}

5,11,17,23-Tetra-tert-butyl-25,26,27,28-tetrakis(chlorocarbonylmethoxy)calix[4]arene

was synthesized following literature methods. ${ }^{23}$

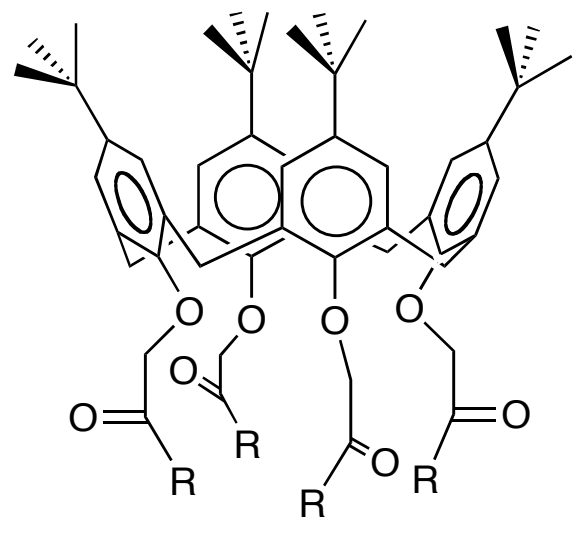<smiles>[R]=CN(C)C(CCC(=O)O)C(=O)O</smiles>

Calixarene syntheses - Aspartate functionalized additive 1. Dimethyl aspartate hydrochloride $(5.20 \mathrm{~g}, 26.3 \mathrm{mmol})$ was dissolved in anhydrous dichloromethane $(80 \mathrm{~mL})$ at $-10^{\circ} \mathrm{C}$ and triethylamine (13 g, $128 \mathrm{mmol})$ was added with stirring. The p-tert-butylcalix[4]arene tetrakis(acid chloride) (2.2g, $2.34 \mathrm{mmol})$ was dissolved separately in anhydrous dichloromethane $(20 \mathrm{~mL})$ and then added at once to the other reactants. The reaction was allowed to reach room temperature and left stirring overnight. The mixture was filtered to remove triethylamine salts and then the filtrate was concentrated by distillation under reduced pressure. The residue was then dissolved in dichloromethane $(200 \mathrm{~mL})$, washed with 
hydrochloric acid (1 M, 3 x $100 \mathrm{~mL})$, sodium hydroxide (0.5 M, 2 x $100 \mathrm{~mL})$, hydrochloric acid again $(1 \mathrm{M}, 100 \mathrm{~mL})$, water $(100 \mathrm{~mL})$ and finally brine $(100 \mathrm{~mL})$. After drying over magnesium sulfate the filtrate was distilled under reduced pressure to yield the methyl ester of $\mathbf{1}$ as a white solid. This was recrystallised from tetrahydrofuran/toluene and the product washed with cold diethyl ether $(920 \mathrm{mg}$, $27 \%$ yield). (Found: C, 62.70; H, 7.09; N, 3.81. $\mathrm{C}_{76} \mathrm{H}_{100} \mathrm{O}_{24} \mathrm{~N}_{4}$ requires $\mathrm{C}, 62.80 ; \mathrm{H}, 6.93 ; \mathrm{N}, 3.85 \%$ ). $\operatorname{NMR}\left(\mathrm{CDCl}_{3}\right):{ }^{1} \mathrm{H}, \delta 1.08\left(\mathrm{~s}, 36 \mathrm{H}, \mathrm{Bu}^{\mathrm{t}}\right), 2.97$ (m, 8H, $\left.\mathrm{CHCH}_{2} \mathrm{COO}\right), 3.21\left(\mathrm{~d}, 4 \mathrm{H}, \mathrm{H}_{\mathrm{eq}} \mathrm{ArCH}_{2} \mathrm{Ar}\right), 3.66$ (s, 12H, $\left.\mathrm{OCH}_{3}\right), 3.73\left(\mathrm{~s}, 12 \mathrm{H}, \mathrm{OCH}_{3}\right), 4.58\left(\mathrm{~d}, 8 \mathrm{H}, \mathrm{OCH}_{2} \mathrm{CO}\right), 4.75\left(\mathrm{~d}, 4 \mathrm{H}, \mathrm{H}_{\mathrm{ax}} \mathrm{ArCH}_{2} \mathrm{Ar}\right), 5.00(\mathrm{~m}, 4 \mathrm{H}$, $\mathrm{CHN}), 6.75(\mathrm{~s}, 8 \mathrm{H}$, aromatic $\mathrm{CH}), 7.97(\mathrm{~d}, 4 \mathrm{H}, \mathrm{NH}) ;{ }^{13} \mathrm{C}, \delta 32.02\left(\mathrm{Me}_{3} \mathrm{C}\right), 32.46\left(\mathrm{ArCH}_{2} \mathrm{Ar}\right), 34.54$ $\left(\mathrm{Me}_{3} \mathrm{C}\right), 36.62\left(\mathrm{CHCH}_{2} \mathrm{COO}\right), 49.38(\mathrm{CHN}), 52.58,53.33(\mathrm{OMe}), 74.72\left(\mathrm{OCH}_{2} \mathrm{CO}\right), 126.27,126.44$, 133.26, 133.62 (aromatic CH), 146.17, 153.83 (aromatic C), $170.71(\mathrm{CONH}), 171.96(\mathrm{COOMe})$.

The methyl ester of $\mathbf{1}(1.00 \mathrm{~g}, 0.69 \mathrm{mmol})$ was heated at reflux in methanol $(130 \mathrm{~mL})$ and then a solution of potassium carbonate $(2.1 \mathrm{~g}, 15.2 \mathrm{mmol})$ in water $(16.4 \mathrm{~mL})$, was added at once. Heating was continued for 2.5 hours. Upon cooling to room temperature, the methanol was removed by distillation under reduced pressure. The remaining solution was made up to $150 \mathrm{~mL}$ with water and then adjusted to pH 2 with 1M hydrochloric acid. The solution was extracted with ethyl acetate (4 x $60 \mathrm{~mL})$ and after drying the combined extracts, the solvent was removed by distillation under reduced pressure. The solid was recrystallised from thf/toluene and then washed with cold ether to yield 1 (872 $\mathrm{mg}, \sim 90 \%$ yield). (Found: C, 59.88; H, 6.73; N, 3.66. $\mathrm{C}_{68} \mathrm{H}_{84} \mathrm{O}_{24} \mathrm{~N}_{4} .2 \mathrm{H}_{2} \mathrm{O}$.thf requires C, 59.66; H, 6.68; N, 3.86\%).

Glutamate functionalized additive 2. The methyl ester of $\mathbf{2}$ was synthesized following the procedure described above to give the product as a white powder in $50 \%$ yield. (Found: C, 63.52; H, 7.14; N, 3.39. $\mathrm{C}_{80} \mathrm{H}_{108} \mathrm{O}_{24} \mathrm{~N}_{4}$ requires $\left.\mathrm{C}, 63.64 ; \mathrm{H}, 7.21 ; \mathrm{N}, 3.71 \%\right)$. NMR $\left(\mathrm{CDCl}_{3}\right):{ }^{1} \mathrm{H}, \delta 1.07\left(\mathrm{~s}, 36 \mathrm{H}, \mathrm{Bu}^{\mathrm{t}}\right), 2.01-2.23$ (m, 8H, $\mathrm{CHCH}_{2} \mathrm{CH}_{2}$ ), 2.24-2.35 (m, 8H, $\left.\mathrm{CH}_{2} \mathrm{CH}_{2} \mathrm{COO}\right), 3.21$ (d, 4H, $\left.\mathrm{H}_{\mathrm{eq}} \mathrm{ArCH}_{2} \mathrm{Ar}\right), 3.66$ (s, 12H, $\left.\mathrm{OCH}_{3}\right), 3.70\left(\mathrm{~s}, 12 \mathrm{H}, \mathrm{OCH}_{3}\right), 4.54\left(\mathrm{~d}, 8 \mathrm{H}, \mathrm{OCH}_{2} \mathrm{CO}\right), 4.66-4.78\left(\mathrm{~d}, \mathrm{~m}, 4 \mathrm{H}+4 \mathrm{H}, \mathrm{H}_{\mathrm{ax}} \operatorname{ArCH}_{2} \mathrm{Ar}, \mathrm{CHN}\right)$, $6.75(\mathrm{~s}, 8 \mathrm{H}$, aromatic $\mathrm{CH}), 7.73(\mathrm{~d}, 4 \mathrm{H}, \mathrm{NH}) ;{ }^{13} \mathrm{C}, \delta 27.57\left(\mathrm{CHCH}_{2} \mathrm{CH}_{2}\right), 30.81\left(\mathrm{CHCH}_{2} \mathrm{COO}\right), 31.98$ $\left(\mathrm{Me}_{3} \mathrm{C}\right), 32.51\left(\mathrm{ArCH}_{2} \mathrm{Ar}\right), 34.52\left(\mathrm{Me}_{3} \mathrm{C}\right), 52.05(\mathrm{CHN})$, 52.29, $53.04(\mathrm{OMe}), 74.76\left(\mathrm{OCH}_{2} \mathrm{CO}\right), 126.11$, 
126.54, 133.28, 134.06 (aromatic CH), 146.23, 153.36 (aromatic C), 170.74 (CONH), 173.13, 173.75

(COOMe).

The methyl ester of $\mathbf{2}$ was hydrolysed as above, and isolated as a white powder after recrystallisation from thf/diethyl ether to yield 2 in $66 \%$ yield. (Found: $\mathrm{C}, 61.55 ; \mathrm{H}, 6.64 ; \mathrm{N}, 3.21 . \mathrm{C}_{72} \mathrm{H}_{92} \mathrm{O}_{24} \mathrm{~N}_{4} \cdot \mathrm{H}_{2} \mathrm{O}$. thf requires $\mathrm{C}, 61.36 ; \mathrm{H}, 6.91 ; \mathrm{N}, 3.77 \%)$.

Calcium carbonate. The impact of additives on the morphology of calcium carbonate was investigated using a method adapted from that of Gower and Tirrell. ${ }^{24}$ Vials containing calcium chloride solutions $(20 \mathrm{~mL}, 7 \mathrm{mmol})$ with appropriate concentrations of additives, were placed in a sealed desiccator ( $20 \mathrm{~cm}$ diameter), along with vials of ammonium carbonate. The vials were covered with laboratory film, with pin-holes to allow diffusion of ammonia and carbon dioxide. Microscope coverslips (11 mm diameter) were placed in the calcium chloride solutions to simplify recovery of the crystals for microscopy. After five days, the crystals were recovered, briefly washed with water, and allowed to dry. After gold-coating, the crystals were examined in a scanning electron microscope.

Autonucleated calcium carbonate precipitation was monitored using a nephelometer probe (Analite NEP 160 from McVan Instruments) with a $90^{\circ}$ detector. The reactor was stirred at $300 \mathrm{rpm}$ using an overhead stirrer. The solution composition was $15 \mathrm{mM} \mathrm{NaHCO}_{3}$ and $19 \mathrm{mM} \mathrm{CaCl}_{2}$, with the required additive concentration.

Barium sulfate. Barium sulfate precipitation experiments were carried out as described previously. ${ }^{25}$ Briefly, precipitation of barium sulfate was monitored in situ using conductivity. The desupersaturation rate was determined as the slope of the linear section of the desupersaturation curve after the induction period. A thermostatted reaction vessel, with glass stirring rod, containing barium chloride $(\sim 0.25 \mathrm{mM})$ solution was allowed to equilibrate before equivalent sodium sulfate was rapidly added to commence the precipitation reaction. The organic additive was added to the initial barium chloride solution at concentrations ranging from 0 to $3.8 \mu \mathrm{M}$. Solids were filtered at the end of the run using a $0.2 \mu \mathrm{m}$ 
membrane, washed with MilliQ water and dried in a dessicator before being prepared for SEM. For those runs where precipitation did not occur on the timescale of the experiment, the solution was left for $>3$ days with a clean glass cover slip at the bottom of the vessel. The glass cover slip was then removed, washed and dried for SEM.

Calcium Oxalate. Calcium oxalate crystals were produced following a literature method reported to produce the monohydrate $(\mathrm{COM}) .{ }^{26}$ In brief, calcium chloride solution was combined with a potassium oxalate solution, in an acetate buffer, to give final concentrations of calcium chloride, $4 \times 10^{-3} \mathrm{M}$, and potassium oxalate, $0.2 \times 10^{-3} \mathrm{M}$. Crystal growth took place over a 48-72 hour period .The additive was introduced over a range of concentrations. The crystals were gold coated and examined in the SEM.

\section{RESULTS AND DISCUSSION}

Additive Synthesis. Calixarenes 1 and $\mathbf{2}$ were synthesized following well established procedures, commencing with the p-tert-butylcalix[4]arene functionalized at the lower rim with acid chloride moieties. ${ }^{23}$ Reaction with the appropriate amino acid methyl ester gave the amino acid functionalized products in reasonable yield. These methyl ester were readily characterized using nmr spectroscopy, with the appearance of the calixarene methylene resonances as a pair of doublets, ${ }^{27}$ and the chemical shift of the methylene carbon in the ${ }^{13} \mathrm{C}$ spectrum, ${ }^{28}$ confirming that the macrocycle is in the cone conformation. After mild hydrolysis to deprotect the amino acid moieties without hydrolyzing the amide links, ${ }^{29}$ the $\mathrm{nmr}$ spectra were significantly broadened. Nevertheless, it was clear that the ester methyl groups are absent in the final products. With stoichiometric addition of sodium hydroxide, both $\mathbf{1}$ and $\mathbf{2}$ are sufficiently soluble to use as crystal growth modifiers in aqueous systems.

Calcium Carbonate Crystallization. Calcium carbonate was crystallized by slow diffusion of carbon dioxide and ammonia (produced by ammonium carbonate) into calcium chloride solutions. In the absence of the calixarene additives, typical calcite rhombs bounded by $\{10.4\}$ faces were obtained, with the occasional appearance of spherical vaterite agglomerates (Figure 1). With the addition of either of the calixarene additives, we detected only calcite, based on direct observation of the crystal 
morphologies and also IR spectroscopy. In the presence of the aspartic acid functionalized calixarene 1, even at concentrations as low as $0.37 \mu \mathrm{M}$, changes in the morphology of the calcite are apparent, with notches in the rhomb edges, progressing to "studded" crystals at higher additive concentrations, where over-growth appears to have taken place on the six rhombohedral surfaces (Fig 1). Aspartic acid monomer, added at equivalent concentrations, did not induce any changes relative to the blank.

A similar morphology to that observed here has been reported for calcite grown in the presence of a helical peptide, modified from an antifreeze peptide by the introduction of aspartic acid residues. ${ }^{10}$ The studded morphology is reported to form under conditions where the peptide is only $40 \%$ helical, and was also found for a number of other polyanionic systems with poorly ordered structures, leading to the suggestion that this morphology results from the calcite surface binding polyanions with no regular conformation. Interestingly, fluorescein labeling showed that this peptide was incorporated into the calcite crystal. 

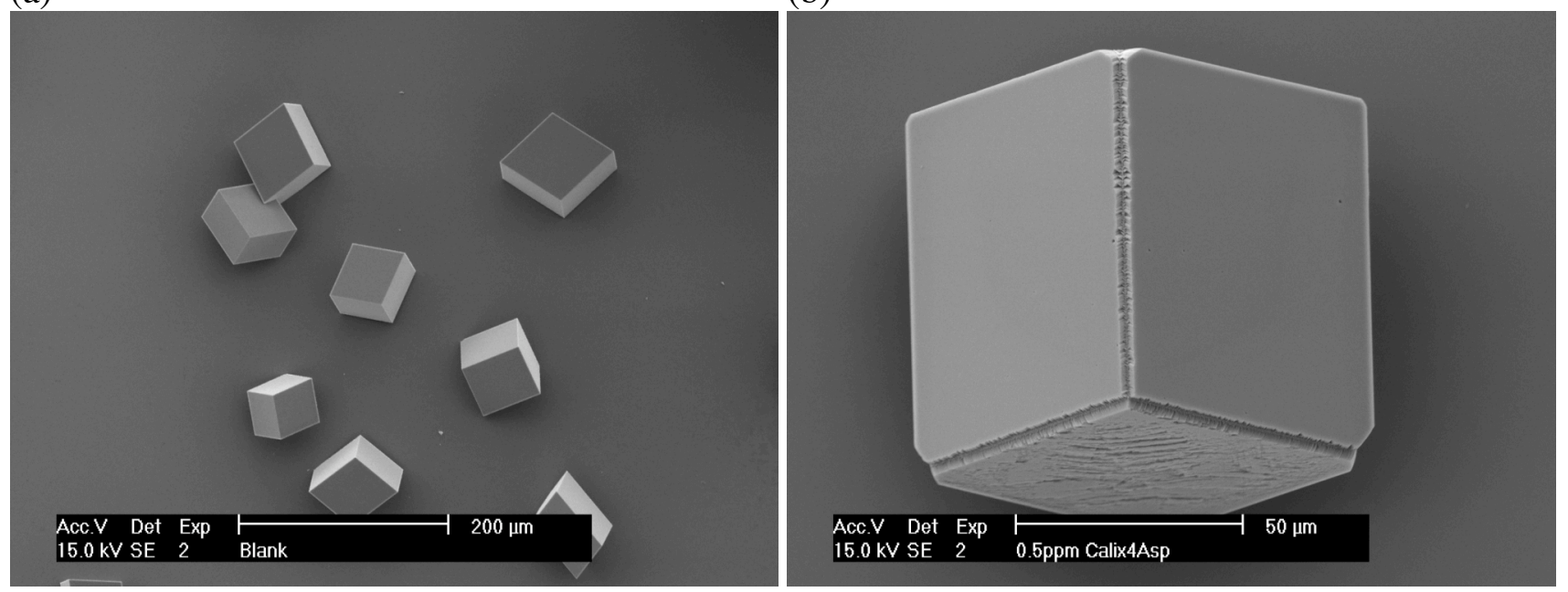

(c)

(d)
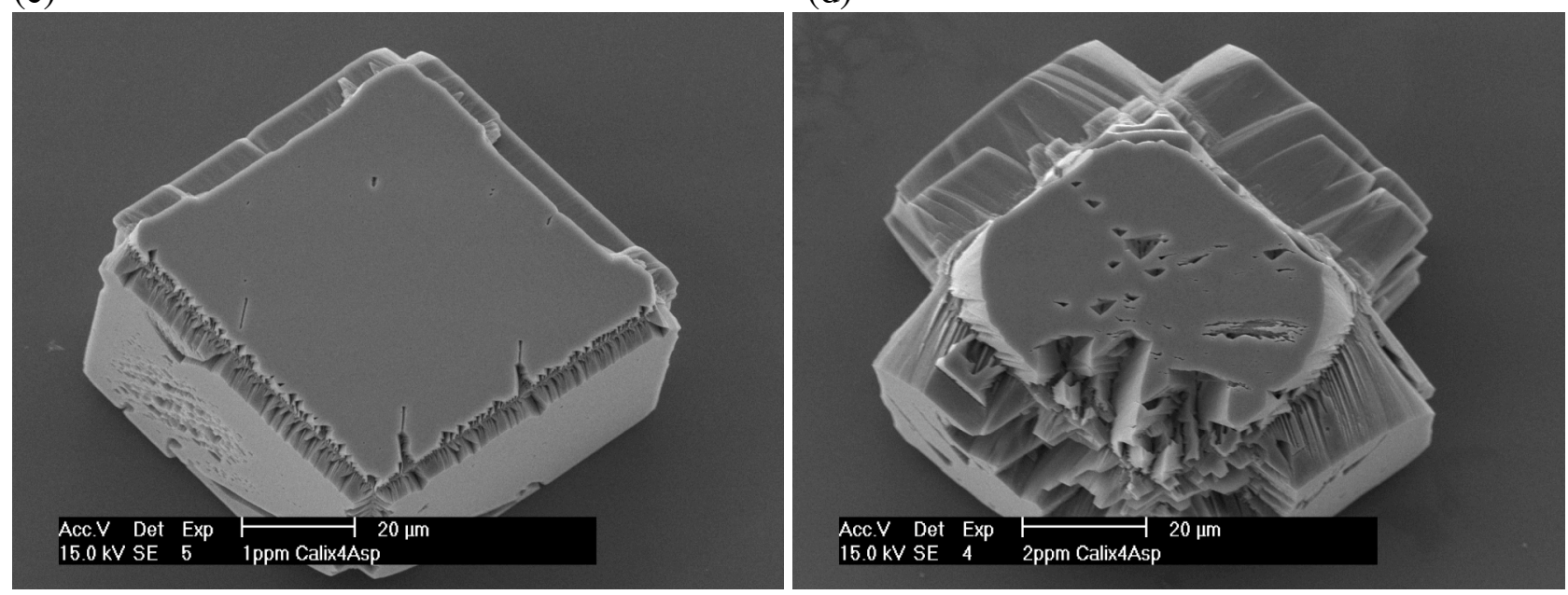

Figure 1. Scanning electron micrographs of calcite crystals grown in the presence of 1. (a) Blank, (b) $0.37 \mu \mathrm{M}$, mole ratio of $\mathbf{1}: \mathrm{Ca}=1: 19000$, (c) $0.74 \mu \mathrm{M}, \mathbf{1}: \mathrm{Ca}=1: 9500$, and (d) $1.5 \mu \mathrm{M}, \mathbf{1}: \mathrm{Ca}=1:$ 4700.

Calcite crystals grown in the presence of the glutamic acid functionalized additive $\mathbf{2}$, exhibited significantly different morphologies, and required higher additive levels to achieve a large impact. Once again, however, equivalent concentrations of the glutamic acid monomer had no discernible impact on the crystal morphology. Two new stepped crystal faces are quite clearly expressed in the modified crystals, and the new faces become increasingly dominant with increasing additive concentration (Figure 2). Amino acids, including aspartic acid, have been reported to bind selectively to the acute steps on the $\{10.4\}$ face, ${ }^{30}$ and similar behaviour is observed here, as shown clearly in Figure 2(c) where 
new stepped faces are much more apparent on the upper faces of the crystal than the lower. The new faces were assigned by comparison of the micrographs with computer-generated morphologies, and by comparison with literature. The new edge faces are tentatively assigned as $\{11.0\}$ faces, and the corner faces as $\{01.2\}$, although it is noted that these faces are severely roughened. These crystals are similar to those produced in the presence of proteins isolated from biological systems such as sea urchin spicules and mollusk shells, where $\{01 . l\}$ faces in particular have been observed in a number of systems. ${ }^{7}$ A remarkably similar morphology has also been reported for calcite grown in the presence of an amphiphilic peptide containing alternating Asp and Phe residues, which is reported as the first peptide that selectively interacts with two different calcite faces. ${ }^{11}$ The fact that calixarene 2 appears to stabilise the same crystal faces, whilst comprising of a completely different structure, requires further investigation of potential additive - crystal interactions. 


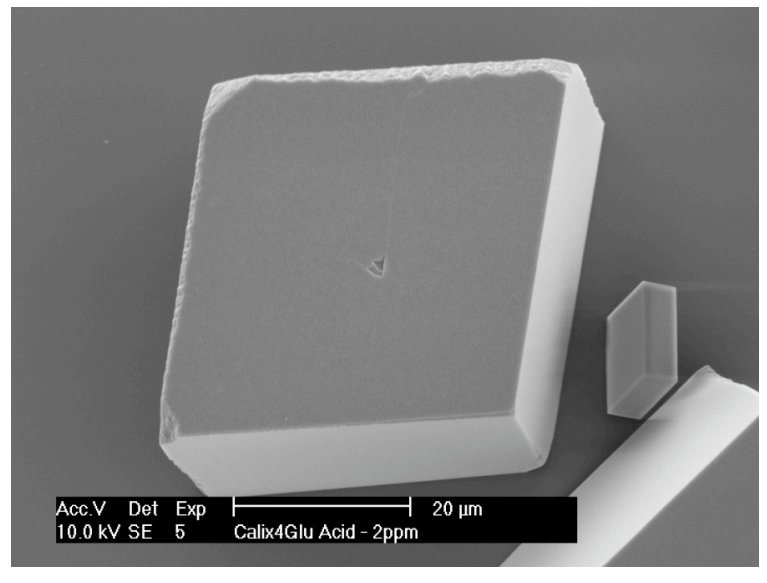

(c)

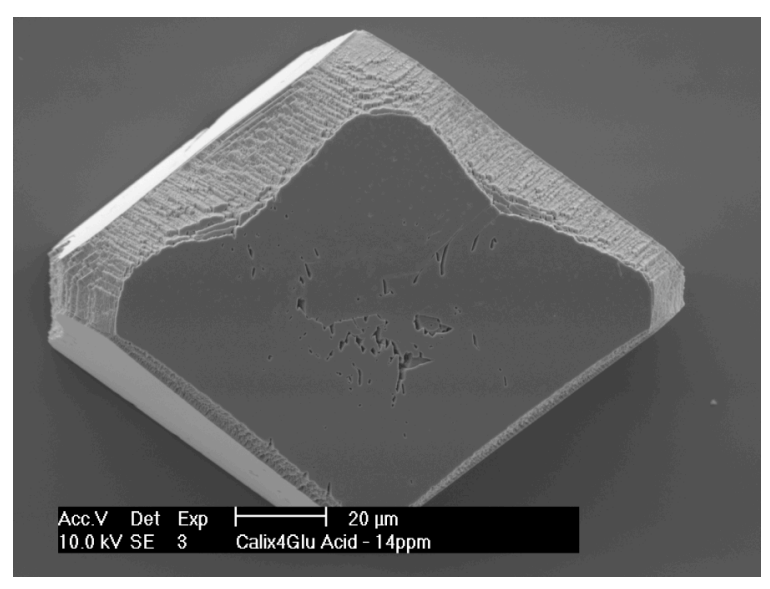

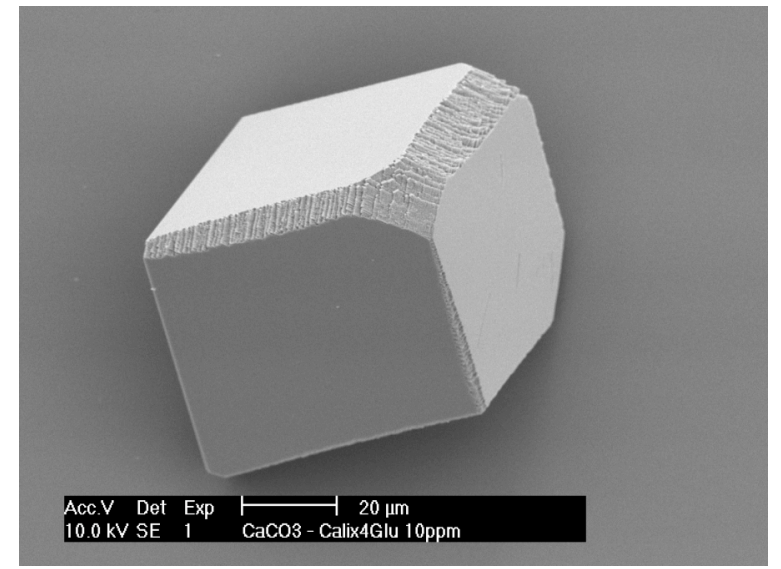

(d)

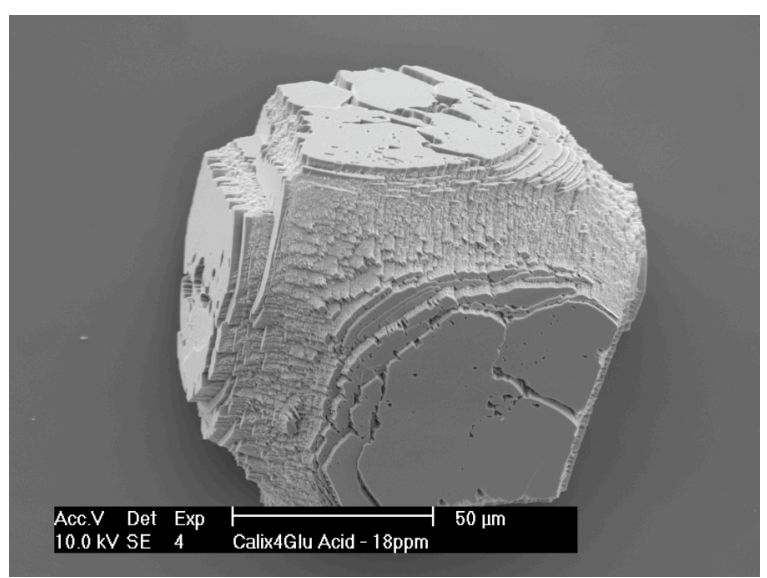

Figure 2. Scanning electron micrographs of calcite crystals grown in the presence of 2. (a) $1.4 \mu \mathrm{M}$, mole ratio of $2: \mathrm{Ca}=1: 5000$ (b) $7.1 \mu \mathrm{M}, \mathbf{2}: \mathrm{Ca}=1: 1000$, (c) $10 \mu \mathrm{M}, \mathbf{2}: \mathrm{Ca}=1: 700$, and (d) 13 $\mu \mathrm{M}, 2: \mathrm{Ca}=1: 540$.

Autonucleation of the calcium carbonate in the presence of the two additives was studied using in situ nephelometry. Both calixarene additives induced a significant lengthening in the induction period (Figure 3). It is interesting to note, however, that the glutamic acid derivative 2, appears to suppress growth over a longer time period than the aspartic additive $\mathbf{1}$, despite the fact that $\mathbf{1}$ has a much greater impact on calcite morphology at lower concentrations when compared to the impact of $\mathbf{2}$. These results, in combination with the "studded" morphology found in the presence of $\mathbf{1}$ (Figure 1), suggest that 1 may be incorporated into the growing calcium carbonate crystals. This may lead to increased crystal growth 
once the solution concentration of the additive is depleted, and would also allow the recovery of the $\{10.4\}$ faces in the slow growth experiments. Further work will be required to investigate this hypothesis.

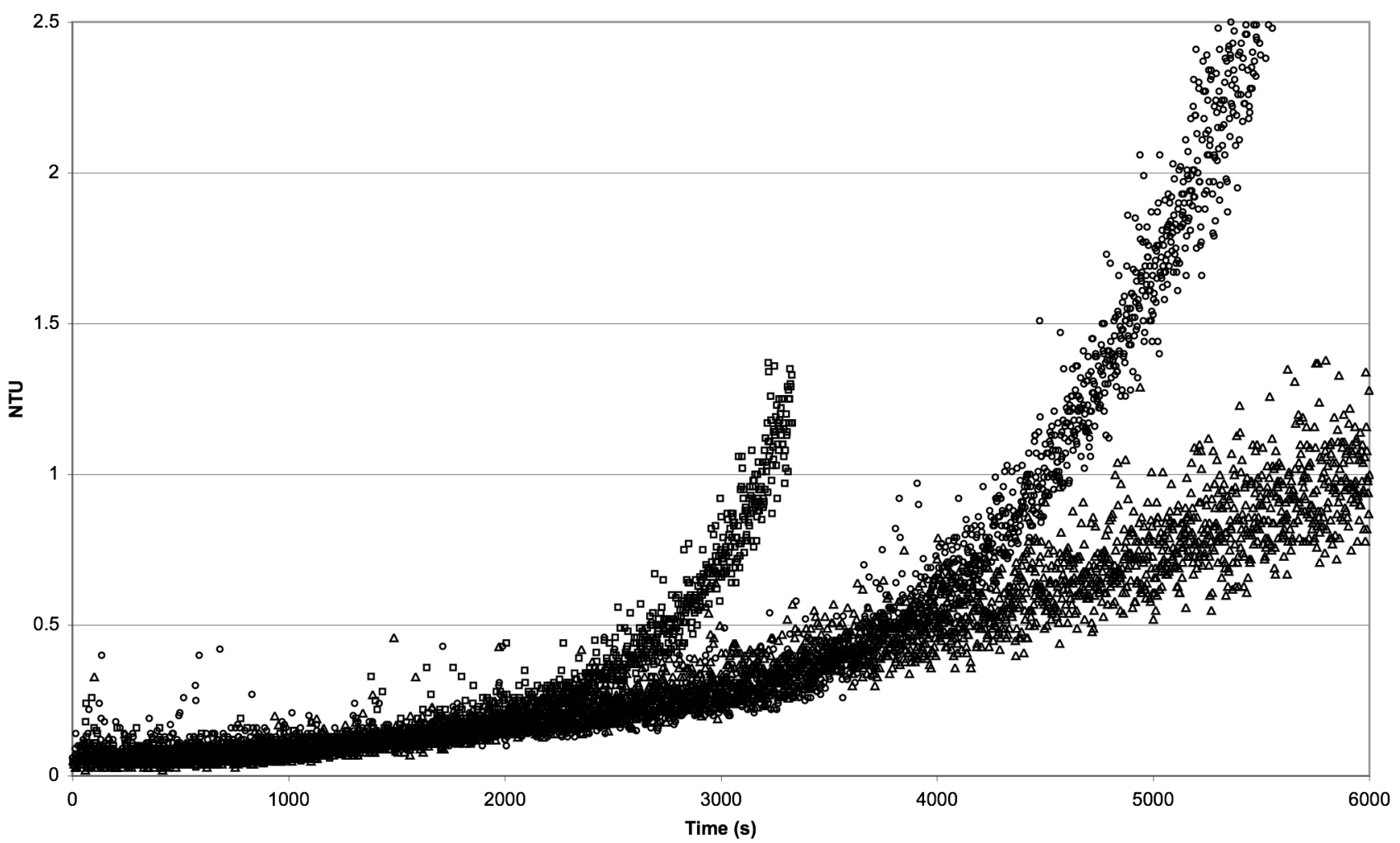

Figure 3. The change in light scattering of supersaturated calcium carbonate solutions over time. Blank, squares; in the presence of $\mathbf{1}$, circles; in the presence of $\mathbf{2}$, triangles (additive concentration $=1.5 \mu \mathrm{M}$ ).

Barium Sulfate Crystallization. Additives 1 and 2 were also tested as barite crystal growth modifiers. Although small molecule barite inhibitors typically involve functional groups such as phosphates and phosphonates, we have observed previously that some small polycarboxylates can modify barite crystallization. ${ }^{13}$ Supersaturated solutions were produced by mixing barium chloride and sodium sulfate solutions, to give an initial barium sulfate concentration of $0.25 \mathrm{mM}$ (supersaturation, ratio, 25). Desupersaturation was monitored by logging conductivity, and the impact of the additives on the relative rate of desupersaturation is shown in Figure 4. 


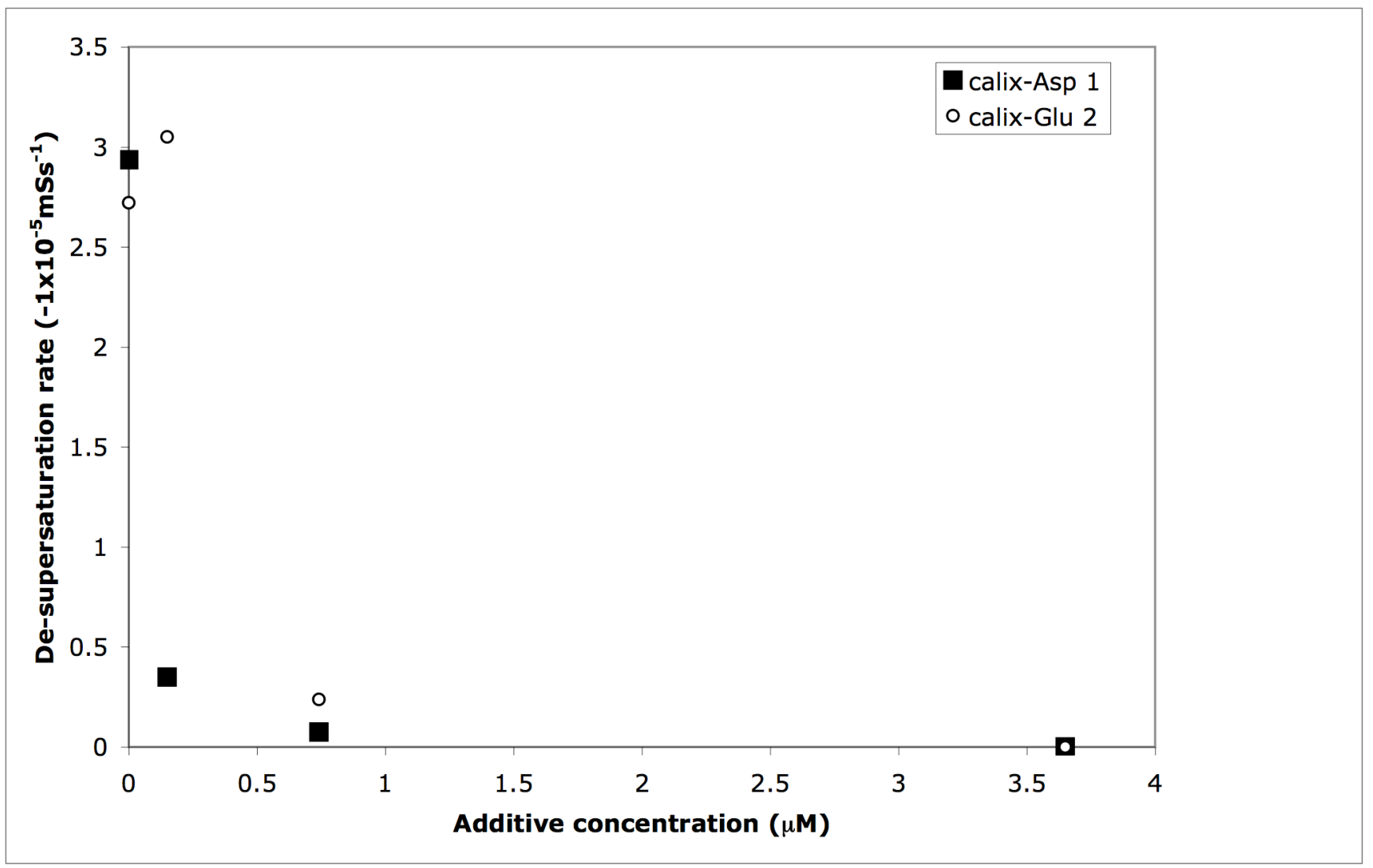

Figure 4. Desupersaturation rates for a barium sulfate solution (supersaturation ratio, 25), with increasing concentrations of additives $\mathbf{1}$ and $\mathbf{2}$.

Both additives completely inhibited crystal growth at a concentration of $3.6 \mu \mathrm{M}$ over the timescale of the experiment, and significantly reduced the growth rate at $0.75 \mu \mathrm{M}$. This compares favourably with the potent polyphosphonate additives we have investigated under comparable conditions, such as ethylenediaminetetraphosphonic acid, which fully inhibits growth at $1.5 \mu \mathrm{M}^{25}$ 
(a)

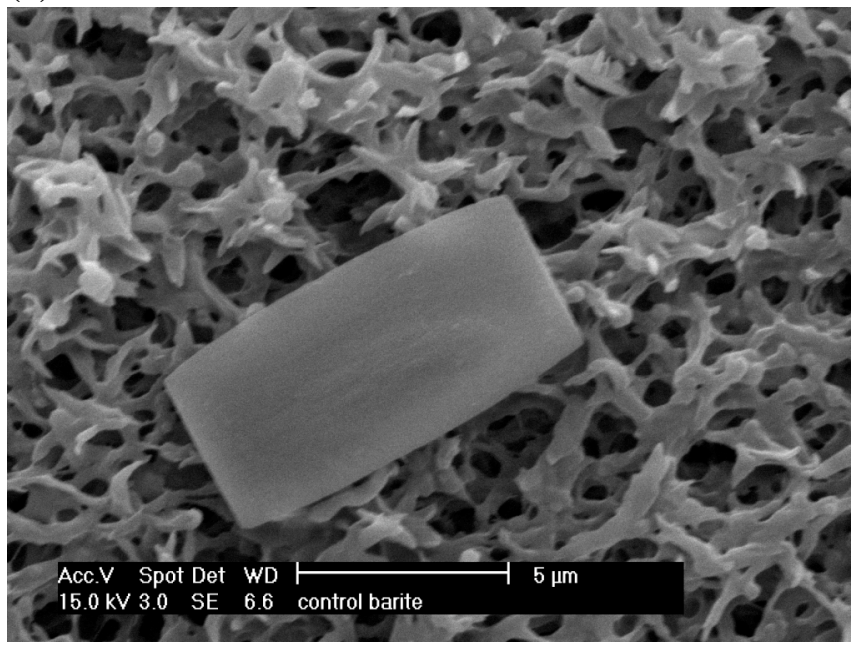

(c)

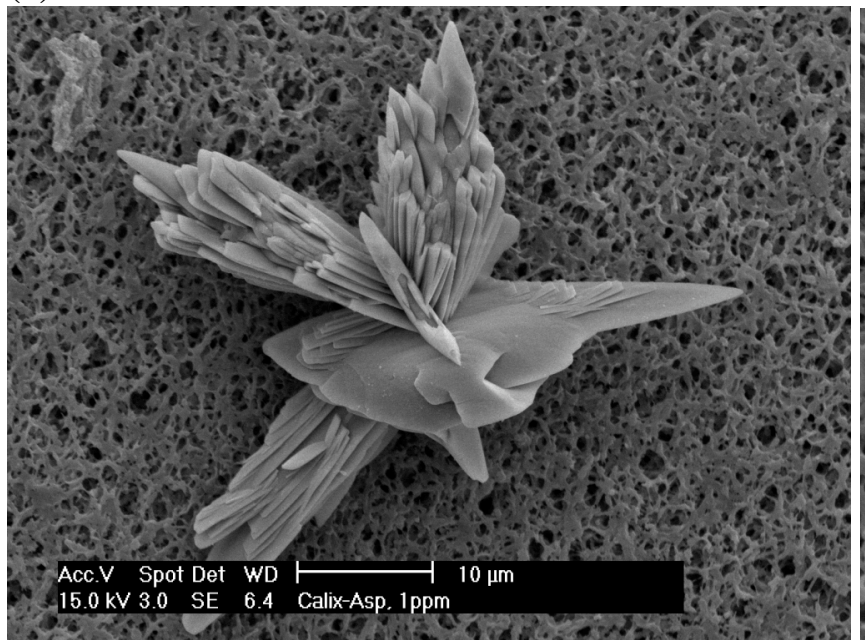

(e)

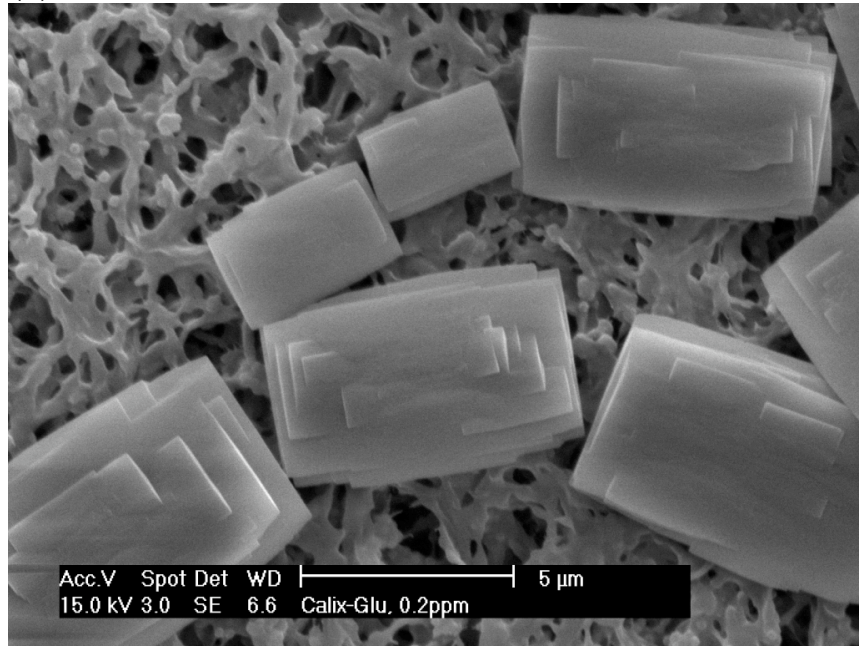

(b)

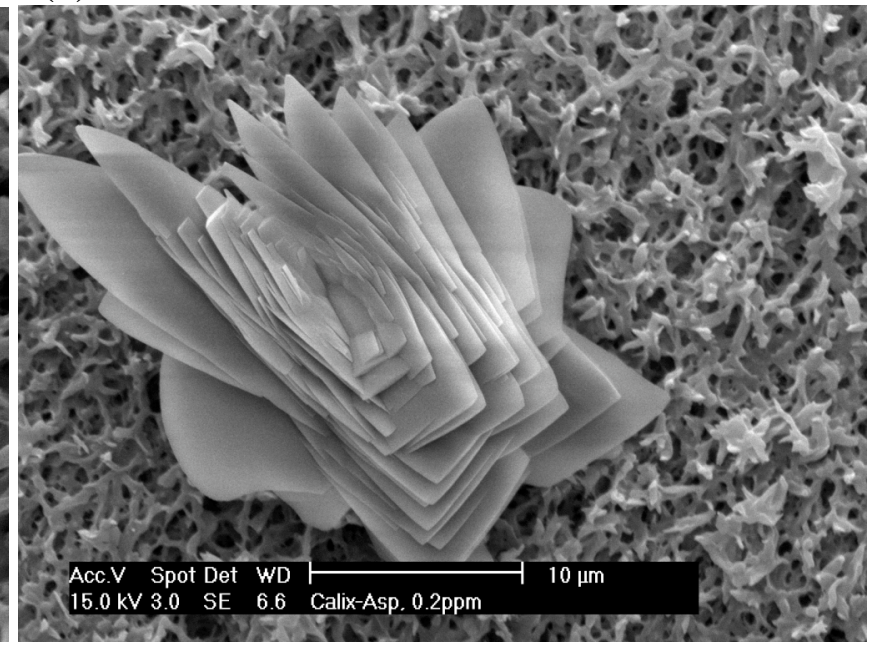

(d)

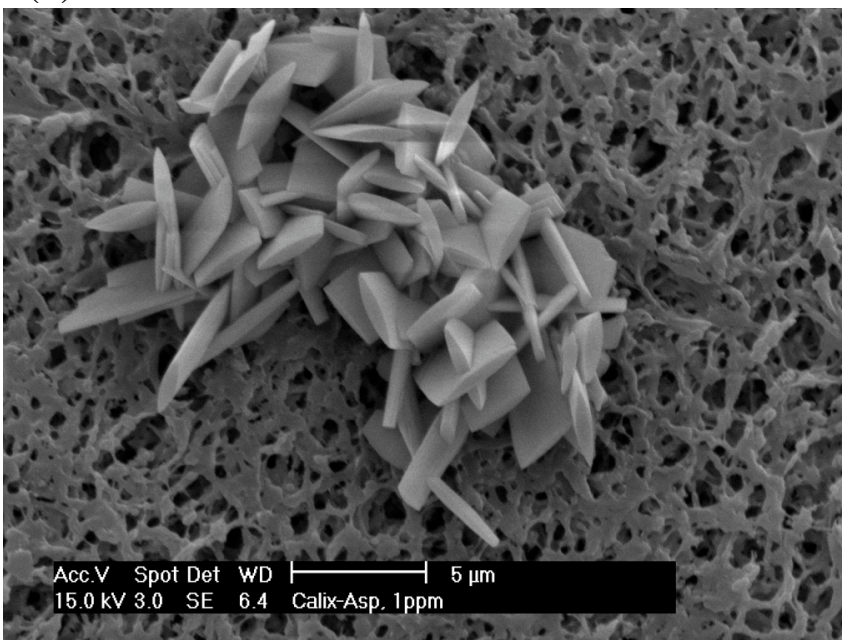

(f)

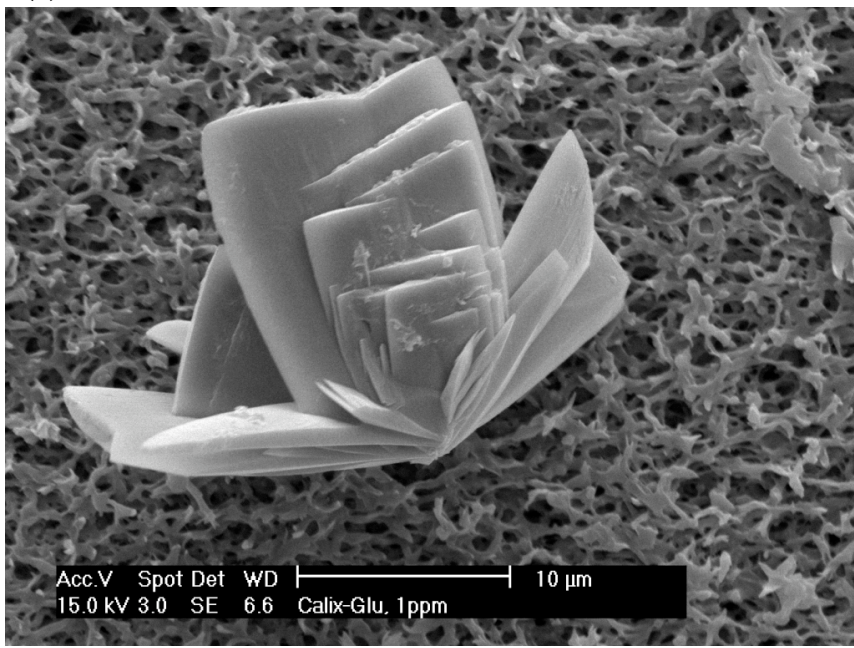

Figure 5. Scanning electron micrographs of barite crystals isolated after desupersaturation rate experiments. (a) Blank, (b) with 1 at $0.15 \mu \mathrm{M}$, (c) 1 at $0.75 \mu \mathrm{M}$, (d) 1 at $0.75 \mu \mathrm{M}$, (e) 2 at $0.15 \mu \mathrm{M}$, and (f) 2 at $0.75 \mu \mathrm{M}$. 
Crystals were isolated at the end of the desupersaturation experiments, and the crystal morphologies examined in the scanning electron microscope. The blank system gave typical barite crystals with the rectangular morphology containing end (001) faces and rounded (hk0) faces. In the presence of additive 1, significantly altered morphologies were observed, consistent with the substantial growth inhibition achieved. The barite appears to be polycrystalline in all cases, and at $0.75 \mu \mathrm{M}$ additive concentration some clusters exhibit elongated morphologies (Figure 5c), and others are agglomerates of smaller crystals with morphologies comparable to the blank system (Figure 5d). The glutamic derivative 2 induces much smaller changes at the lowest concentration (Figure 5e) consistent with a lack of growth inhibition (Figure 4), although some polycrystallinity is indicated in the micrograph. At $0.75 \mu \mathrm{M}$ of $\mathbf{2}$, the barite crystal clusters are comparable to those produced in the presence of $\mathbf{1}$ (Figure 5f).

Polyaspartic acid of varying molecular weight has been investigated as a barium sulfate inhibitor previously. ${ }^{31}$ This work showed that inhibition by polyaspartic acid is comparable to polyacrylates and optimal inhibition occurred when 15-30 monomer units formed the polymer (in fact in the presence of $1.56 \mu \mathrm{M}$ of a 3,200 MW polyaspartic acid, barite precipitation was inhibited by $78 \%$ - this represents 24 monomer units each with one carboxylate group). In the present work described, 4 monomer units of aspartic acid are bound to the calixarene, each with two carboxylate groups, and $3.6 \mu \mathrm{M}$ is sufficient to completely inhibit precipitation. Thus, in terms of concentration of carboxylate moieties, polyaspartic acid achieved $78 \%$ inhibition at $37.4 \mu \mathrm{M}$, whereas the calixarene $\mathbf{1}$ achieved $100 \%$ inhibition at 28.8 $\mu \mathrm{M}$. This implies that, in fact, the aspartic acid functionalized calixarene is a more potent crystal growth inhibitor than polyaspartic acid. Conducting a barite precipitation run in the presence of aspartic acid at $17 \mu \mathrm{M}$ (a higher concentration than the equivalent aspartic acid present in a $3.6 \mu \mathrm{M}$ solution of 1) showed only a marginal reduction in de-supersaturation rate (control $\sim-3.0 \times 10^{-5} \mathrm{mSs}^{-1}$, with aspartic present $\sim-2.3 \times 10^{-5} \mathrm{mSs}^{-1}$ ). To the best of the authors' knowledge there is no literature showing the same morphological changes to barite as those observed here. Certainly, polymers have been shown to produce polycrystalline structures, which can self-aggregate to form more complex shapes. ${ }^{32}$ 
Unfortunately, the paper reporting the impact of polyaspartic acid, discussed above, contains no images. $^{31}$

Calcium Oxalate Crystallization. Calcium oxalate is a biomineral found in plants, and is a constituent of kidney stones. ${ }^{33,34}$ The interaction of proteins and the inorganic component in kidney stones is an area of significant interest, ${ }^{35}$ and hence it was of interest to compare the impact of additives $\mathbf{1}$ and $\mathbf{2}$ on the crystal growth of calcium oxalate. Calcium oxalate typically crystallizes as one of three hydrates; the thermodynamically stable monohydrate (COM), and the metastable dihydrate (COD) and trihydrate (COT). ${ }^{34}$ We have shown previously that additive 1 stabilizes COD under conditions where $\mathrm{COM}$ is otherwise produced..$^{22}$ A typical COM crystal produced in the absence of additives is shown in Figure 6(a). The morphology of COD crystallized in the presence of $\mathbf{1}$ is shown in Figure 6(b), with relatively smooth pyramidal $\{101\}$ faces, and severely roughened prismatic $\{100\}$ faces. As the concentration of $\mathbf{1}$ is increased, the COD crystals lengthen slightly and the $\{101\}$ faces roughen (not shown). For concentrations of $2.2 \mu \mathrm{M}$ and higher, the crystals formed were predominantly COD, although the additive appears to inhibit nucleation effectively, and the number of crystals formed dropped significantly with increasing additive concentration. We confirmed the assignment of the phase of these crystals, and samples mentioned below, using Raman microscopy to collect spectra of individual crystals. $^{36}$ 


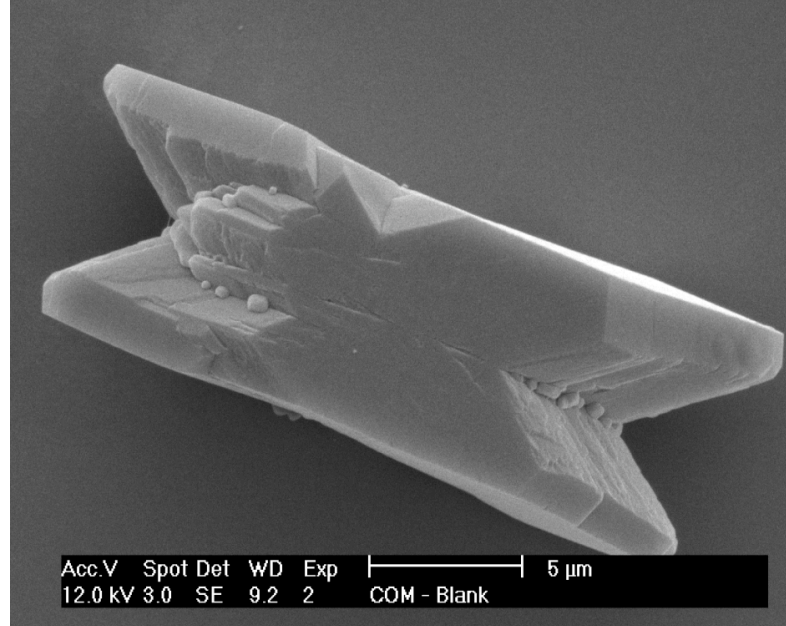

(c)

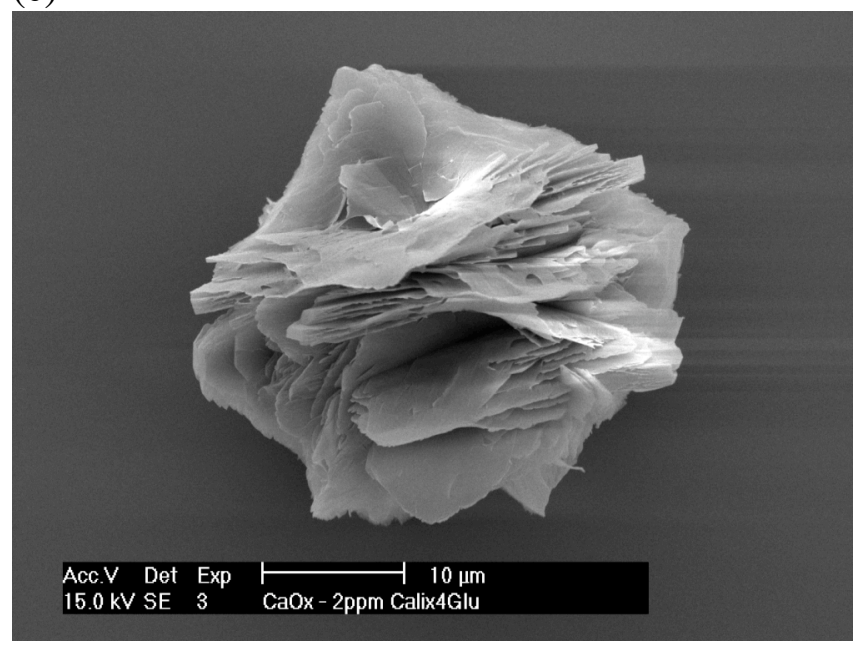

(e)

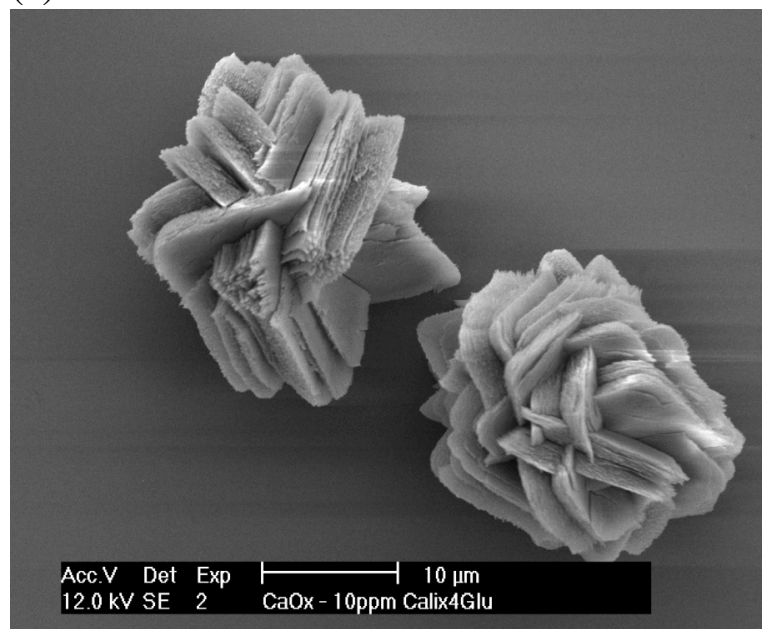

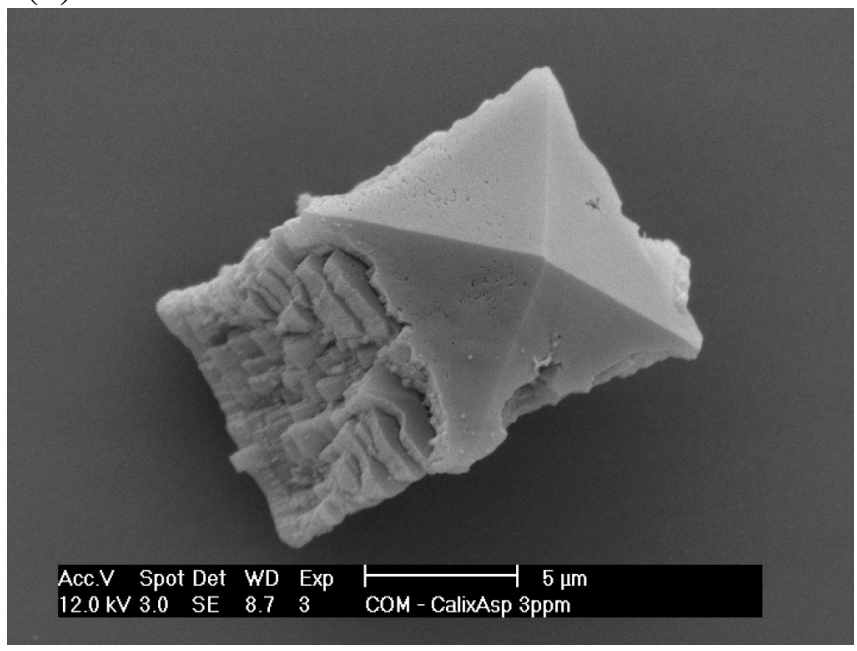

(d)

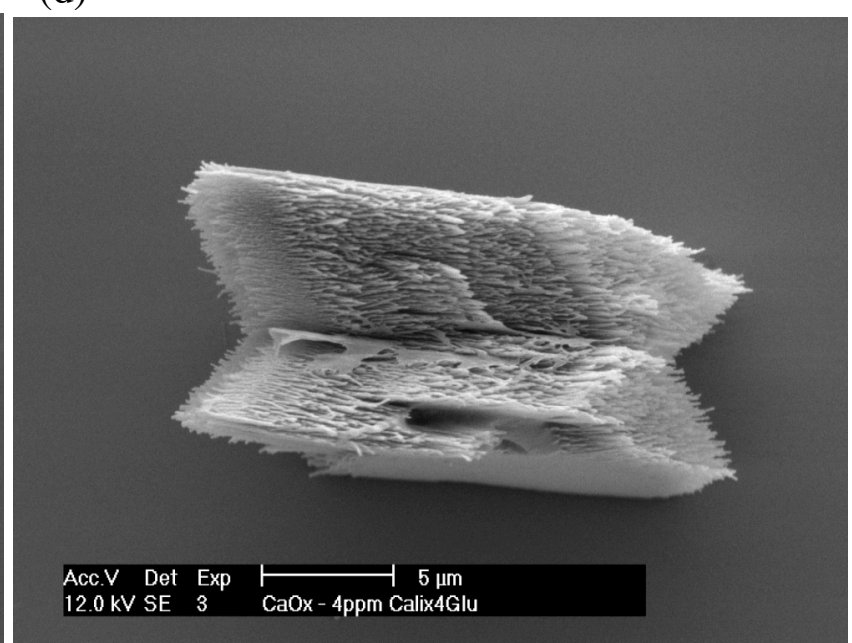

(f)

Figure 6. Scanning electron micrographs of calcium oxalate crystals isolated in the presence of calixarene additives 1 and 2. (a) Blank, (b) with 1 at $2.2 \mu \mathrm{M}$, (c) 2 at $1.4 \mu \mathrm{M}$, (d) 2 at $2.9 \mu \mathrm{M}$, (e) 2 at $7.2 \mu \mathrm{M}$, and (f) 2 at $11 \mu \mathrm{M}$. 
Calcium oxalate crystallized in the presence of glutamic calixarene $\mathbf{2}$ exhibited different behaviour. The crystalline product was dominated by COM, albeit with altered morphologies up to concentrations of 7.2 $\mu \mathrm{M}$. The COM was found either as clusters of thin plates (Figure 6c, e), or as severely roughened, possibly polycrystalline deposits with an overall morphology comparable to that of COM found in the blank (Figure 6d). Further increase of the additive concentration resulted in the formation of COD crystals comparable to those produced in the presence of $\mathbf{1}$ (Figure 6f), although once again, significant inhibition was observed with very few crystals produced.

These observations are comparable to those reported for the crystallization of calcium oxalate in the presence of polyaspartic and polyglutamic acids. ${ }^{37}$ Polyaspartic acid is reported to stabilize COD (most effective molecular weight range $12-15 \mathrm{kDa}$ ), although in this case no elongation of the COD bipyramids was apparent (based on optical microscopy observations). Polyglutamic acid (13 kDa) induced altered morphologies of COM, described as dumbbell-like, again based on optical micrographs. At higher concentrations of polyglutamic acid, COD was formed as bipyramids. A carboxylated block copolymer has been reported to produce elongated COD crystals with dominant $\{100\}$ faces. ${ }^{34}$ Interestingly, the $\{100\}$ faces in these crystals appear smooth, whereas the two calixarene additives induce significant roughening of these faces.

\section{CONCLUSION}

The impact of two amino acid functionalized calixarenes on the crystal growth of three different inorganic systems has been investigated. The results indicate that these relatively low molecular weight additives can induce changes comparable to those achieved by much larger polymeric additives with similar functional groups. In some cases, the changes in morphology are remarkably similar to those produced in the presence of proteins derived from natural systems. Work is now underway to study these additives in more detail, using a combination of computational studies, and further experimental studies of systematically altered calixarene additives. 


\section{REFERENCES}

1. Lowenstam, H. A.; Weiner, S., On Biomineralization. Oxford University Press: Oxford, 1989.

2. Mann, S., Biomineralization. VCH: Weinheim, 1989.

3. Jones, F.; Rohl, A. L.; Ogden, M. I.; Parkinson, G. M., Materials Forum 2001, 25, 116.

4. Braga, D., Angew. Chem., Int. Ed. Engl. 2003, 115, 5544.

5. Aizenberg, J.; Weiner, S.; Addadi, L., Connect. Tissue Res. 2003, 44, 20.

6. Thompson, J. B.; Paloczi, G. T.; Kindt, J. H.; Michenfelder, M.; Smith, B. L.; Stucky, G.;

Morse, D. E.; Hansma, P. K., Biophys. J. 2000, 79, 3307.

7. Aizenberg, J.; Lambert, G.; Weiner, S.; Addadi, L., J. Am. Chem. Soc. 2002, 124, 32.

8. $\quad$ Li, C.; Botsaris, G. D.; Kaplan, D. L., Cryst. Growth Des. 2002, 2, 387.

9. Volkmer, D.; Fricke, M.; Huber, T.; Sewald, N., Chem. Commun. 2004, 1872.

10. DeOliveira, D. B.; Laursen, R. A., J. Am. Chem. Soc. 1997, 119, 10627.

11. Estroff, L. A.; Incarvito, C. D.; Hamilton, A. D., J. Am. Chem. Soc. 2004, 126, 2.

12. Naka, K.; Chujo, Y., Chem. Mater. 2001, 13, 3245.

13. Jones, F.; Clegg, J.; Oliveira, A.; Rohl, A. L.; Ogden, M. I.; Parkinson, G. M.; Fogg, A. M.;

Reyhani, M. M., CrystEngComm 2001, 40, 1.

14. Asfari, Z.; Böhmer, V.; Harrowfield, J. M.; Vicens, J., Calixarenes 2001. Kluwer: Dordrecht, $2001 ;$ p 683.

15. Bosbach, D.; Coveney, P. V.; Griffin, J. L. W.; Putnis, A.; Risthaus, P.; Stackhouse, S.; Whiting, A., J. Chem. Soc., Perkin Trans. 2 2002, 1238.

16. Coveney, P. V.; Davey, R.; Griffin, J. L. W.; He, Y.; Hamlin, J. D.; Stackhouse, S.; Whiting, A., J. Am. Chem. Soc. 2000, 122, 11557.

17. Lahiri, J.; Xu, G.; Dabbs, D. M.; Yao, N.; Aksay, I. A.; Groves, J. T., J. Am. Chem. Soc. 1997, $119,5449$.

18. Volkmer, D.; Fricke, M., Z. Anorg. Allg. Chem. 2003, 629, 2381. 
19. Volkmer, D.; Fricke, M.; Agena, C.; Mattay, J., J. Mater. Chem. 2004, 14, 2249.

20. Volkmer, D.; Fricke, M.; Vollhardt, D.; Siegel, S., J. Chem. Soc., Dalton Trans. 2002, 4547.

21. DiMasi, E.; Olszta, M. J.; Patel, V. M.; Gower, L. B., CrystEngComm 2003, 5, 346.

22. Bartlett, M. J.; Mocerino, M.; Ogden, M. I.; Oliveira, A.; Parkinson, G. M.; Pettersen, J. K.;

Reyhani, M. M., J. Mater. Sci. Tech. 2005, 21, 1.

23. McKervey, M. A.; Seward, E. M.; Ferguson, G.; Ruhl, B.; Harris, S. J., J. Chem. Soc., Chem. Commun. 1985, 383.

24. Gower, L. A.; Tirrell, D. A., J. Cryst. Growth 1998, 191, 153.

25. Jones, F.; Oliveira, A.; Rohl, A. L.; Parkinson, G. M.; Ogden, M. I.; Reyhani, M. M., J. Cryst. Growth 2002, 237-239, 424.

26. Shirane, Y.; Kurokawa, Y.; Miyashita, S.; Komatsu, H.; Kagawa, S., Urol. Res. 1999, $27,426$.

27. Gutsche, C. D.; Dhawam, B.; Levine, J. A.; No, K. H.; Bauer, L. J., Tetrahedron 1983, $39,409$.

28. Jaime, C.; de Mendoza, J.; Prados, P.; Nieto, P. M.; Sánchez, C., J. Chem. Soc., Dalton Trans. 1991, 3479.

29. Arnaud-Neu, F.; Barboso, S.; Casnati, A.; Pinalli, A.; Schwing-Weill, M.; Ungaro, R., New J. Chem. 2000, 24, 967.

30. Orme, C. A.; Noy, A.; Wierzbicki, A.; McBride, M. T.; Grantham, M.; Teng, H. H.; Dove, P. M.; DeYoreo, J. J., Nature 2001, 411, 775.

31. Ross, R. J.; Low, K. C.; Shannon, J. E., Mater. Perform. 1997, 36, 53.

32. Qi, L.; Cölfen, H.; Antonietti, M., Chem. Mater. 2000, 12, 2392.

33. Bouropoulos, N.; Weiner, S.; Addadi, L., Chem. Eur. J. 2001, 7, 1881.

34. Zhang, D.; Qi, L.; Ma, J.; Cheng, H., Chem. Mater. 2002, 14, 2450.

35. Touryan, L. A.; Clark, R. H.; Gurney, R. W.; Stayton, P. S.; Kahr, B.; Vogel, V., J. Cryst. Growth 2001, 233, 380.

36. Letellier, S. R.; Lochhead, M. J.; Campbell, A. A.; Vogel, V., Biochim. Biophys. Acta 1998, 
1380, 31 .

37. Wesson, J. A.; Worcester, E. M.; Kleinman, J. G., J. Urol. 2000, 163, 1343. 
For Table of Contents use only:

Calix[4]arenes, functionalized at the lower rim with aspartic or glutamic acid, are found to be potent crystal growth modifiers for inorganic crystals, including calcite, barite and calcium oxalate. The impact of these novel crystal growth modifiers is found to be comparable to polymers and proteins, of much higher molecular weight in some cases, in terms of morphology modification and phase deposited.
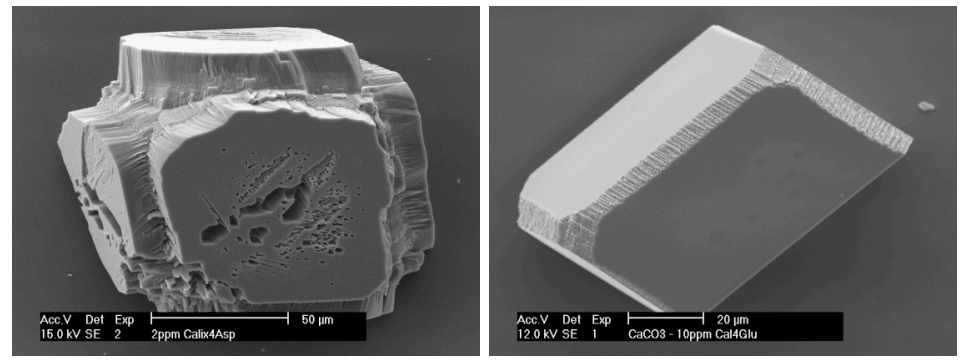